\title{
DIVERSITY OF BIRDS ACROSS LAND USE AND HABITAT GRADIENTS IN FORESTS, RUBBER AGROFORESTS AND RUBBER PLANTATIONS OF NORTH SUMATRA
}

\author{
Asep Ayat ${ }^{1, *}$ and Hesti L. Tata ${ }^{2}$ \\ ${ }^{1}$ Burung Indonesia, Jalan Dadali 32, Bogor 16161, Indonesia \\ ${ }^{2}$ Forest Research and Development Center, Jl. Gunung Batu 5, Bogor, Indonesia
}

Received: 31 March 2014, Revised: 10 May 2014, Accepted: 11 October 2015

\begin{abstract}
DIVERSITY OF BIRDS ACROSS LAND USE AND HABITAT GRADIENTS IN FORESTS, RUBBER AGROFORESTS AND RUBBER PLANTATIONS OF NORTH SUMATRA. Birds play a pivotal role in the ecosystem, but in disturbed areas their roles may be limited due to the changes of their natural habitats. This paper studies the birds' habitats in Simalungun and Asahan Districts, North Sumatra. The study was conducted in four habitats: natural forest, rubber agroforests, rubber monoculture plantations and emplacement areas. The birds were observed using descriptive survey methods by implementing a quick biodiversity survey, data were collected along one $\mathrm{km}$ transect. The results showed that in total, 142 species of birds from 42 families were observed in the four habitats. Natural forests had the highest diversity of bird species, followed by rubber agroforests, emplacement areas and rubber plantations, with a Shannon-Wiener index of 3.8, 3.6, 3.0 and 2.9, respectively. Regarding the IUCN red list species, 12 bird species of nearthreatened status and 2 species of vulnerable status were recorded. Based on CITES categories, one species was listed in the Appendix I, 12 species were classified in Appendix II and 26 bird species were protected under Indonesian regulations. Changes in the structure and composition of the vegetation in disturbed forests and cleared land determined the richness of the bird species. The different tree compositions in the four habitats of the rubber estate plantations and surrounding areas influenced the number of bird species, bird diversity and species composition.
\end{abstract}

Keywords: Species composition, conservation, CITES, guild type

KERAGAMAN JENIS BURUNG PADA BERBAGAI PEMANFAATAN LAHAN DAN GRADASI DI HUTAN, AGROFOREST KARET DAN PERKEBUNAN KARET DI SUMATERA UTARA. Burung berperan penting dalam ekosistem, namun pada ekosistem yang terganggu peran mereka menjadi terbatas akibat perubahan babitat. Studi komunitas burung di berbagai tipe habitat, pada butan, agroforest karet, monokultur karet dan daerah pemukiman telah dilakukan di Kabupaten Simalungun dan Asahan, Provinsi Sumatra Utara. Burung diamati dengan melakukan survei deskriptif dengan metode survei cepat biodiversitas, dengan mengkoleksi data pada transek sepanjang 1 km. Hasil studi di keempat tipe babitat menjumpai 142 jenis burung dari 42 suku. Burung yang dijumpai di butan memiliki tingkat keragaman jenis tertinggi, selanjutnya habitat karet agroforest, daerah pemukiman dan karet monokultur, memiliki tingkat keragaman jenis yang lebih rendah, dengan index Shannon-Wiener secara berturut-turut 3,8, 3,6, 3,0 dan 2,9. Tercatat 12 jenis burung dengan status kelangkaan terancam punah dan dua species dengan status rentan, menurut red-list IUCN. Berdasarkan kategori CITES, tercatat satu jenis burung yang termasuk. Appendix I, 12 jenis burung yang termasuk Appendix II, dan 26 jenis burung yang dilindungi berdasarkan peraturan perundang-undangan di Indonesia. Perubaban struktur dan komposisi vegetasi di butan yang terganggu dan lahan terbuka menentukan kekayaan jenis burung. Perbedaan komposisi jenis pohon di keempat habitat di sekitar perkebunan karet monokultur mempengarubi jumlah, keragaman, dan komposisi jenis burung.

Kata kunci: Komposisi jenis, konservasi, CITES, relung pakan

*Corresponding author: asep.ayat@gmail.com 


\section{INTRODUCTION}

Sumatra has the lowest number of endemic bird species in Indonesia. This is related to its geological history of separation from the plains of Asia. Sumatra has about 306 bird species that are also found in Borneo, 345 species that can be found in the Malayan Peninsula and 211 species that also live in Java (MacKinnon \& Phillips, 1993). A total of 583 recorded species inhabit the island of Sumatra and 438 species are breeding in Sumatra (Andrew, 1992). These numbers increase to 602 and 450 species, respectively when we include the small islands along the coast of Sumatra. There are 12 endemic bird species in the lowlands of Sumatra (Marle \& Marle, 1988).

North Sumatra is covered by natural forests including Batang Gadis, Bohorok, Batang Toru and other forested areas, although most of these forests are fragmented and under considerable pressure from land-use changes (MacKinnon, Phillips, \& van Balen, 1998; Sirait, 2007). Human activities change natural environments, such as turning forest into agricultural land, plantations and infrastructure for industrial activities. Forest areas of Sumatra remained at about 30\% (13 million ha) of the total area of Sumatra in 2007 (Laumonier et al., 2010). Forest losses cause loss of bird habitat and decrease the number of bird species (Danielsen \& Heegard, 1995; O'Brien \& Kinnaird, 1996; Lane et al., 2011). Besides hunting and trade, deforestation and habitat destruction are the most dominant drivers in reducing the number of bird species and their possible extinction.

Agroforestry may reconcile ecological and economic objectives, balancing the need to generate income along with protecting the environment (Nair \& Garrity, 2012). In 2005, agroforests covered about 16.3 million ha, or $8 \%$ of the total area of Indonesia (ICRAF, 2011). Rubber agroforests (RAFs) are part of Sumatra's man-made ecosystem and have been used by farmers for many decades. Farmers with limited resources plant rubber trees within the agroforestry system and manage the farm extensively. Rubber agroforests include a mixture of trees, lianas, shrubs and herbaceous plants. Monoculture rubber plantations are managed by companies and farmers with greater resources. The basal area of rubber monocultures is lower than that in the natural forest, because there are no large trees in the plantations (van Noordwijk, Tata, Xu, Dewi, \& Minang, 2012; Tata, van Noordwijk, \& Werger, 2008).

In conservation, it is important to analyse the response of birds to habitat fragmentation and the diversity found in a fragmented habitat, such as rubber monocultures. Bird conservation activities tend to be focused on protected natural forests (NF) and emphasise threatened species faced with extinction, but most of the remaining forest in Sumatra is secondary (Ekadinata \& Vincent, 2011). Currently little attention is given to common species or species that inhabit secondary forests and agroecosystems, such as rubber agroforests (RAF) and rubber monocultures (RMP). This paper studies at Simalungun and Asahan Districts, North Sumatra, Indonesia bird richness and diversity, the composition of bird communities and their roles in secondary and primary forests, RAF systems, rubber monoculture (RMP) and emplacement areas (EA) of RMP.

\section{MATERIAL AND METHOD}

\section{A. Study Area}

The study was conducted from December 2010 to January 2011 in four habitat types: NF, RMP, RAF, and EA, in the Districts of Simalungun and Asahan in North Sumatra Province, Indonesia $\left(02^{\circ} 43^{\prime} 4^{\prime}\right.$ 'N and $98^{\circ} 56^{\prime 25}$ 'E) (Figure 1). The EA was located inside the rubber plantations. The RMPs have been intensively managed for many years with regular fertilisation, weeding and tapping, which affected the condition of the vegetation. The rubber stands in the RMP were grouped based on ages: 2-6 years, 12-15 years, and 2225 years after planting. Two RAF plots were located in the surroundings of the RMPs. RAF plots were managed with less fertilisation and weeding. Other trees were allowed to grow on these farms, creating mixed vegetation of 

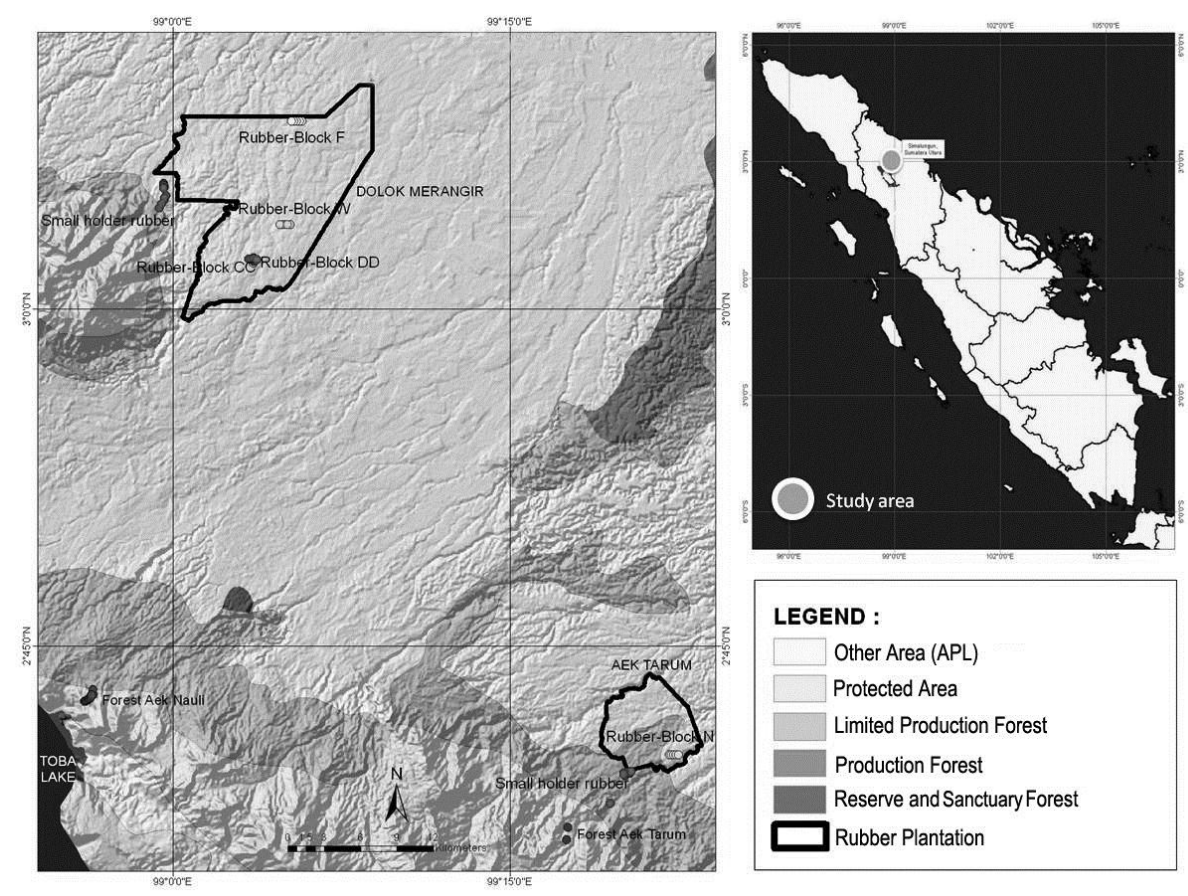

Figure 1. Study sites in Dolok Merangir (Simalungun District) and Aek Tarum (Asahan District), North Sumatra.

simple agroforestry system.

Forest plots were located in two sites: Aek Nauli (Bartong) forest research area in Dolok Merangir, Simalungun District and Aek Tarum forest in Asahan District. The elevation of the forest plots ranged from $1200 \mathrm{~m}$ to $1300 \mathrm{~m}$ above sea level (asl). The size of the Aek Tarum study area was 79,944.5 ha, and the Dolok Merangir study area was 139,353.93 ha. Each study site included RAFs, RMPs and EAs.

\section{B. Data Collection}

The birds were observed by descriptive survey methods using a quick biodiversity survey (QBSur) for birds (Tata et al., 2013), where data were collected along a $1 \mathrm{~km}$ transect, in total 12 transects; and from the list of 20 MacKinnon's bird species (MacKinnon \& Phillips, 1993) simultaneously in four habitat types (e.g. NF, RMP, RAF, EA). The survey was completed within two weeks. The MacKinnon's list is an established method used to record and verify species and to calculate bird densities. Data was tabulated and birds were identified using this nomenclature (Sukmantoro et al., 2007).
Composition of guilds, which are defined as a group of species using the same resource in the same way, was adapted from Wiens (1989), the threat of fragmentation of bird species refers to Lambert and Collar (Lambert \& Collar, 2002), while IUCN status refers to the IUCN Red List (IUCN, 2012).

\section{Data Analysis}

Comparison of abundance was calculated from the percentage ratio of the individual numbers of a species compared to the total individual number that was caught. Diversity was calculated using the Shannon-Wiener index (Magurran, 1988).

The Shannon-Wiener index was used to determine the diversity of mammal species on each transect (Krebs, 1999) and is described by the following equation:

$$
\mathrm{H}^{\prime}=\sum_{i=1}^{n}-(\text { pi ln pi })
$$

where,

$\mathrm{H}^{\prime}=$ Shannon-Wiener diversity index

pi $=$ Probability of species (relative density)

$\mathrm{n}=$ Number of species 
Evenness index (E') was used to estimate the evenness of the species distribution of the birds (Krebs, 1999) and is described by the following equation:

$$
E^{\prime}=\frac{H}{\ln s}
$$

where,

$\mathrm{H}^{\prime}=$ Shannon-Wiener diversity index

$\mathrm{S}=$ Number of species

Each bird species found in the study area was recorded in a list containing the names of the first 20 species encountered, after which a new list of the recording began. This list was used to generate a curve of bird species' richness among different sites. Observations were made twice a day, in the morning from 06:00 to $11: 00$ and in the afternoon from 15:00 to 17:30 (except on rainy days). Tools used in this activity were binoculars (Bushnell 10 x 25), GPS Garmin Oregon 300, a digital voice recorder (Olympus WS-560M) and a Nikon D80 (70-300 mm Tele Lens). Two field identification guides were used (King, Woodcock, \& Dickinson, 1975; MacKinnnon \& Phillips, 1993).

\section{RESULT AND DISCUSSION}

\section{A. Bird Richness and Diversity}

In total, 142 species of birds from 42 families were recorded across all the areas (Appendix 1). From the total bird species recorded, 122 species were found in the NF, 30 in the RMP, 39 in the EA and 46 in the RAF. A total of 728 individual birds were observed across different habitats. Encountered species richness, abundance, diversity and density are summarized in Table 1 and Figure 2. NF was the most diverse in bird species, indicated by a Shannon-Wiener index of 3.8, followed by RAF (3.6), EA (3.0) and RMP (2.9). All bird species were distributed evenly in every types of habitat, as shown by the evenness index value of almost 1 (ranged 0.87-0.94).

In general, the richness of bird species in North Sumatra was high. Of the 1,589 bird species found in Indonesia, 583 were found in Sumatra (Andrew, 1992). Rubber plantations and surrounding areas in the two Districts of North Sumatra have 124 of the total bird species of Sumatra or $8.9 \%$ of the whole of Indonesia.

The species' richness in Simalungun and Asahan area (142 species) was close to the richness of bird species encountered in Batang Toru (Jihad, 2009). RAF in Bungo, Jambi Province had even higher species richness (167 bird species) (Joshi et al., 2002). For comparison, in the forest habitat of Bukit Barisan Selatan National Park (Jambi-Sumatra), 276 bird species were found (O’Brien \& Kinnaird, 1996).

The highest bird species' richness occurs in NF habitat (122 species), followed by RAF (46 species), EA (39 species) and RMP (30 species). Bird species were more diverse at the two NF sites than those in RAFs and RMPs. Although Aek Nauli was categorised as disturbed forest, bird composition was similar to that of the natural forest of Aek Tarum. Bird species richness in the three habitats decreased sharply from 122 species in the forest to 46 species in RAF to only 18 species in RMP (see Table 1 ).

The number of species in the RMP was the lowest, except along river banks, which have more diverse vegetation. RAF had greater richness of species compared with EA and RMP. Many food trees and trees suitable for nesting were still available in the RAF, such as durian (Durio zybetbinus), candle nuts (Aleurites mollucana) and other fruit trees. RAF provides a compatible bird habitat, with mixed vegetation composed of fruit trees, such as durian (Durio zibethinus), duku (Lansium domesticum), jengkol (Pithecellobium lobatum), mangosteen (Garcinia mangostana) and cacao (Theobroma cacao). The mixed vegetations attract birds searching for food and nesting materials. In addition, RAFs provide a comfortable habitat, especially for the Helmeted Hornbill (Rhinoplax vigi). The bird species in the EA were fewer than those in RAF, although there were some food trees for birds, such as Ficus and other fruit trees.

Bird diversity at a given site may also 
Table 1. Statistical summary of birds in the study areas of Simalungun and Asahan Districts, North Sumatra

\begin{tabular}{lcccc}
\hline Habitat Types & Abundance & $\begin{array}{l}\text { Species } \\
\text { Number }\end{array}$ & $\mathbf{H}^{\prime}$ & $\mathbf{E}^{\mathbf{\prime}}$ \\
\hline NF & 267 & 122 & 3.8 & 0.94 \\
RMP & 147 & 30 & 2.9 & 0.88 \\
$2-6$ yr & 49 & 15 & 2.5 & 0.91 \\
$12-15$ yr & 37 & 18 & 2.7 & 0.95 \\
$22-25$ yr & 56 & 20 & 2.6 & 0.87 \\
RAF & 103 & 46 & 3.6 & 0.94 \\
EA & 211 & 39 & 3.0 & 0.84 \\
\hline
\end{tabular}

Remarks : H'= Shannon-Wiener index, E'=Evenness index

$\mathrm{NF}=$ natural forests at a protected forest area in Aek Tarum and a research forest area in Aek Nauli Rubber Agroforest $(\mathrm{RAF})=$ mixed rubber trees with other valuable trees to form simple agroforestry system

Rubber Monoculture Plantation (RMP)=Young rubber plantation (2-6 years), medium rubber plantation (12-15 years) and older rubber plantation (22-25 years)

Emplacement Area $(E A)=$ Settlement area of a rubber plantation with mixed fruit trees

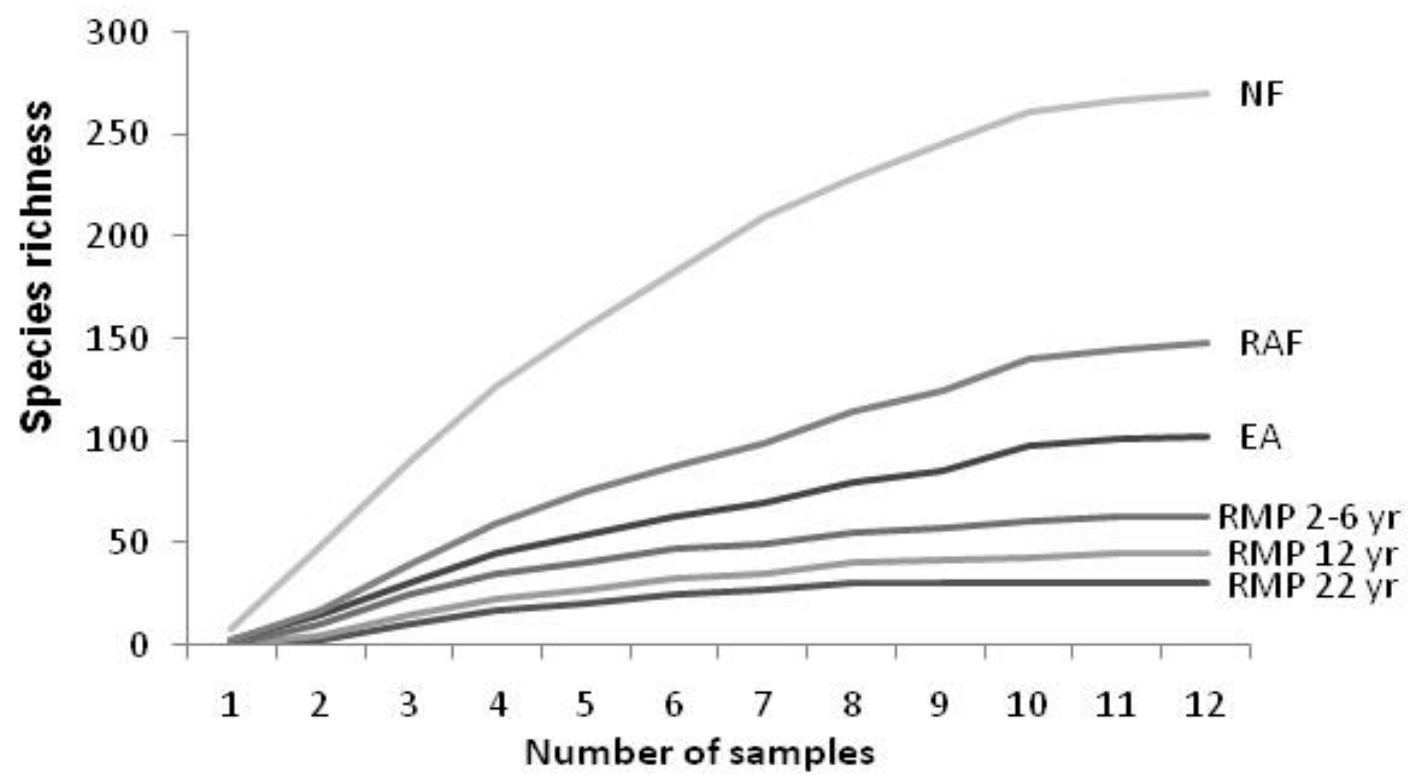

Figure 2. Species accumulation curves by habitat types (Natural Forests=NF, Rubber Agroforests $=$ RAF, Emplacement Areas $=\mathrm{EA}$ and 3 differently aged Rubber Monoculture Plantations=RMP)

reflect a high biodiversity of other wildlife in the ecosystem (McNeely, 1988; Yoza, 2000). Bird species diversity in North Sumatra varied between 3.8 in forests to 2.9 in RMP areas. The diversity of bird species depends on environmental conditions. Species diversity decreased in the land use gradient from
NF to RMP, which relates to a decrease in environmental factors, such as structure and composition of the vegetation. Among the four habitats, the basal area of vegetation in RMP was the lowest owing to fewer large trees growing in monocultures. Bird diversity in RMP was categorised as 'middle value', based on 
the Shannon-Wienner index. Environmental factors, such as canopy height, diversity of tree species, and crop coverage, determine the diversity of bird species (Welty, 1982). The decline in bird diversity is related to the decline of carrying capacity.

\section{B. Bird Composition}

The birds in the ecosystem were classified according to their roles. There were 17 guilds represented: arboreal frugivore (AF), arboreal foliage gleaning insectivore (AFGI), arboreal foliage gleaning insectivore-frugivore (AFGIF), arboreal frugivore-predator (AFP), aerial insectivore (AL), bark gleaning insectivore (BGI), miscellaneous insectivore-piscivore (MIP), nectarivore $(\mathrm{N})$, nocturnal predator (NP), nectarivore-insectivore-frugivore (NIF), piscivore $(\mathrm{P})$, raptor $(\mathrm{R})$, sallying insectivore $(\mathrm{SI})$, sallying substrate gleaning insectivore (SSGI), terrestrial frugivore (TF), terrestrial insectivore (TI) and terrestrial insectivore-frugivore (TIF) (Figure 3).

The guilds were further categorised, based on feeding habits, into eight groups, namely frugivore, insectivore, nectarivore, nocturnal predator, insectivore-frugivore, piscivore, raptor and omnivore (Figure 4). Bird species composition in the rubber plantation was different from the three other habitats; two feeding groups of birds, i.e. omnivores and nectarivores, were not found. Aratrakorn et al. (2006) also found different bird composition and guild types in forest compared with oil palm and rubber plantation. Nectarivores birds are not found in oil palm and rubber plantations in southern Thailand.

The differences in the guild composition of the open-canopy areas (RMP) and closedcanopy areas (forest) indicated that the RAF

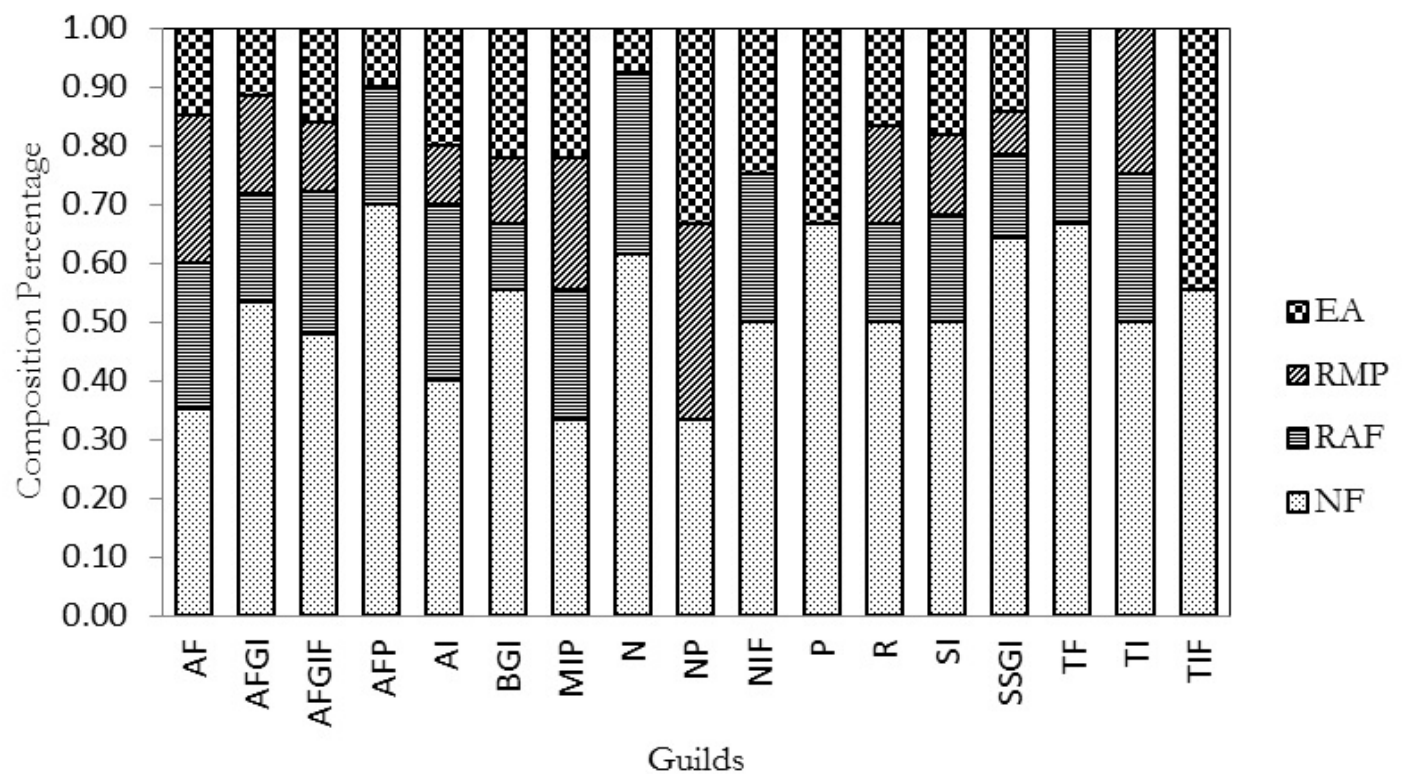

Figure 3. Bird composition guilds according to their roles in four habitats in Simalungun and Asahan Districts, North Sumatra. AF $=$ arboreal frugivore; AFGI $=$ arboreal foliage gleaning insectivore; AFGIF = arboreal foliage gleaning insectivore-frugivore; AFP $=$ arboreal frugivore-predator; $\mathrm{AI}=$ aerial insectivore; $\mathrm{BGI}=$ bark gleaning insectivore; $\mathrm{MIP}=$ miscellaneous insectivore-piscivore; $\mathrm{N}=$ nectarivore $\mathrm{NP}=$ nocturnal predator; $\mathrm{NIF}=$ nectarivore-insectivore-frugivore; $\mathrm{P}=$ pinsivore; $\mathrm{R}=$ raptor; $\mathrm{SI}=$ sallying insectivore; SSGI = sallying substrate gleaning insectivore; $\mathrm{TF}=$ terrestrial frugivore; $\mathrm{TI}=$ terrestrial insectivore; and $\mathrm{TIF}=$ terrestrial insectivore-frugivore 
areas were transition areas between forest and RMP, making rubber agroforest the second choice after forests as habitat for bird nesting, foraging, and breeding (Figure 4).

Species that were absent from bird communities in different habitats (forests, RAF, RMP and EA) allowed comparison of habitat function. In general, species composition was dominated by insect-eaters (insectivores) and seed or fruit-eaters (frugivores). Each type of forest, e.g. primary forest at Aek Tarum and secondary forest at Aek Nauli education-forest, contained similar bird species. While RAFs and RMPs held different species compared to both the primary and secondary forests. Groups of insectivores, which were not found in RMPs, play the role as pollinators, as they feed on nectar and transfer pollen at the same time. However, rubber is not pollinated by birds, but usually through controlled pollination by insects
(Warmke, 1952). Rubber monocultures do not provide a suitable environment for specific bird species with particular roles.

The difference in guild composition between open-canopy areas (such as rubber plantations) and closed-canopy areas (such as natural forest) indicate that RAF and smallholder rubber plantations provide a transition area between forests and RMP. Insectivores, frugivores, and nectarivores were commonly found in secondary forests and the more open forest fringes, whereas arboreal frugivores, terrestrial frugivores and bark gleaning insectivores prefer to live in the middle of the forest.

Bird species in North Sumatra as shown in Figure 4 are dominated by the Nectariniidae and Pycnonotidae families. These birds prefer to live in secondary forests, forest edges and settlements (MacKinnon et al., 1998), where insects and nectar are available. Other studies
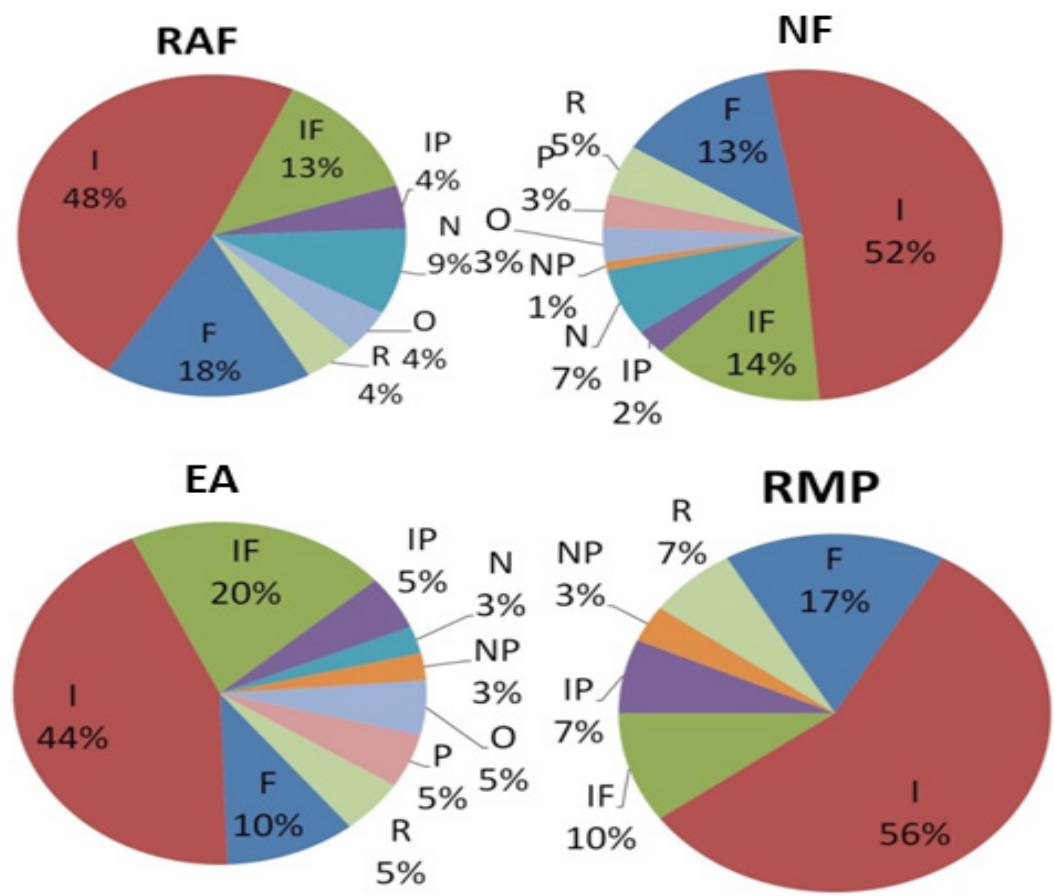

Figure 4. Bird composition guilds based on feeding habitat in four habitat types in Simalungun and Asahan Districts, North Sumatra

Remarks : F = frugivore (AF, AFGI, AFGIF, AFP, TF); I = insectivore (AI, BGI, MIP, SI, SSG, TI); N = nectarivore; $\mathrm{NP}=$ nocturnal predator; $\mathrm{IF}=$ insectivore-frugivore; $(\mathrm{TIF}), \mathrm{P}=$ piscivore; $\mathrm{R}=$ raptor; and $\mathrm{O}=\mathrm{Omnivore}$ (NIF) 
show that bird communities are usually dominated by a few specific types, which have a high relative abundance, and most other species are much rarer (Karr, Schemske, \& Brokaw, 1983; Prawiradilaga, Astuti, Marakarmah, Wijayamukti, \& Kundarmasno, 2002).

Based on the guild feeding groups, species' compositions in forests and RAF were relatively similar, dominated by the insectivores and frugivores, and followed by nectarivores, piscivores, raptor and granivores. Bird communities in the study area clearly showed a mix of the species that prefer the central parts of forests (Picidae, Capitonidae, Trogonidae, Pittidae) and forest edges (such as Pycnonotidae, Nectariniidae, Sylviidae, Laniidae, Timaliidae). In the forests, we found frugivores (Bucerotidae, Capitonidae, Columbidae, Pycnonotidae, Decidae and Chloropsidae) suggesting the presence of fruit trees. Fruit trees create a good ecosystem for many species, providing refuge, perches and food.

Rubber monoculture plantations where food is depleted, has less support on birdlife. Therefore, an ecotone such as riparian and emplacement, is important as an intermediary region between two adjacent ecosystems. An ecotone allows various types of life which are better adapted to changes in the environment (Fitri \& Ford, 2003). The diversity of bird species in an ecotone is a combination of species from the surrounding areas. Hence, bird species diversity in an ecotone is usually higher than that of the surrounding area (Odum, 1971; Baker, French, \& Whelan, 2002).

Bird composition in rubber plantations was clearly different from bird composition in RAF. Only four guild groups of birds were found in RMP: insectivores, frugivores, piscivores and raptors. The other four groups found in the forests were not encountered in RMP. Bird compositions in the three differently aged stands of rubber trees were not significantly different. Bird types were dominated by Alcedinidae, Pycnonotidae, Strigidae, Apodidae, Sylviidae, Cuculidae and Columbiae. Insectivorous groups comprised large percentage in plantation areas and were present in large numbers in all habitat types. We observed insectivore birds, such as Yellow-vented Bulbul (Pycnonotus goiavier), Common Tailorbird (Orthotomus sutorius), Ashy Tailorbird (Orthotomus ruficeps) and Yellowbrowed Warbler (Phylloscopus inornatus). Various insectivore-piscivore species were abundant in the plantations, like White-throated Kingfisher (Halcyon smyrnensis) and Collared Kingfisher (Halcyon chloris). There were also groups of nocturnal predators, which play an important role in maintaining the biological balance, such as the Buffy Fish-Owl (Ketupa ketupu).

Birds play a role in controlling insect populations, consuming up to one third of their body weight (Hernowo, Soekmadi, \& Ekaelawan, 1991) daily. Of the 494 bird species found in Java, 331 (67\%) are insectivorous, with 24 percent of these being primary insectivores, and $76 \%$ secondary insect eaters (Andrew, 1992). Some insects such as Orthoptera (grasshoppers, crickets), Homoptera (leafhoppers, mites) and Heteroptera (ladybugs) are pests on plants, and therefore the insectivore birds play an important biological control in the ecosystem.

Frugivorous birds act as a dispersal agent for plants (Welty, 1982). Nectarivores birds act as polinators (MacKinnon \& Phillips, 1993). Birds also help nitrogen and phosphorus cycles (Odum, 1971). High numbers of large arboreal frugivores were encountered in the rubber plantation, such as Spotted Dove (Streptopelia chinensis) and Zebra Dove (Geopelia striata). In addition, two groups of birds were found in the ground-cover of the rubber plantation in all stand-ages, namely sallying insectivores and arboreal foliage gleaning-insectivores, such as the Tiger Shrike (Lanius tigrinus) and Hill Prinia (Prinia atrogularis). Velvet bean (Mucuna) as a cover crop provided insect food for these two species.

Different compositions of bird communities were found in the EA. Emplacement sites, which are located inside the RMP, were planted with a variety of large trees. Some trees, such as ficus, pine, palm, banana, mango, rambutan and cocoa and woody-tree species provide 
Table 2. Status of birds according to IUCN, CITES and Indonesian law

\begin{tabular}{|c|c|c|c|c|c|c|c|c|}
\hline \multirow[b]{2}{*}{ Scientific Name } & \multirow[b]{2}{*}{ English Name } & \multicolumn{3}{|c|}{ Status } & \multicolumn{4}{|c|}{ Habitats } \\
\hline & & $\mathrm{IUCN}^{1}$ & CITES $^{2}$ & $\begin{array}{c}\text { UU/ } \\
\text { PP RI }^{3}\end{array}$ & NF & RMP & RAF & EA \\
\hline Ardea alba & Great Egret & & & $\mathrm{AB}$ & $\#$ & & & \\
\hline Egretta garzetta & Little Egret & & & $\mathrm{AB}$ & $\#$ & & & \\
\hline Haliastur indus & Brahminy Kite & & II & $\mathrm{AB}$ & \# & & & \\
\hline Haliaeetus leucogaster & White-bellied Sea Eagle & & II & $\mathrm{AB}$ & \# & & & \\
\hline Ictinaetus malayensis & Black Eagle & & II & $\mathrm{AB}$ & $\#$ & & \# & $\#$ \\
\hline Spizaetus cirrbatus & Crested Hawk-Eagle & & II & $\mathrm{AB}$ & \# & & & $\#$ \\
\hline Spizaetus alboniger & Blyth's Hawk-Eagle & & II & $\mathrm{AB}$ & \# & & & \\
\hline Spilornis cheela & Crested Serpent Eagle & & II & $\mathrm{AB}$ & \# & \# & \# & \\
\hline Accipiter virgatus & Besra & & II & $\mathrm{AB}$ & & $\#$ & & \\
\hline Argusianus argus & Great Argus & NT & II & $\mathrm{AB}$ & \# & & & \\
\hline Treron capellei & Large Green Pigeon & VU & & & \# & & & \\
\hline Loriculus galgulus & Blue-crowned Hanging Parrot & & II & & \# & & \# & \\
\hline Rhopodytes diardi & Black-bellied Malkoha & NT & & & $\#$ & & & \\
\hline Tyto alba & Barn Owl & & II & & & & & $\#$ \\
\hline Ketupa kеtuри & Buffy Fish-Owl & & II & & & $\#$ & & \\
\hline Glaucidium brodiei & Collared Owlet & & II & & $\#$ & & & \\
\hline Collocalia vulcanorum & Volcano Swiftlet & NT & & & \# & & & \\
\hline Harpactes kasumba & Red-naped Trogon & NT & & $\mathrm{AB}$ & \# & & & \\
\hline Alcedo meninting & Blue-eared Kingfisher & & & $\mathrm{AB}$ & \# & & & \\
\hline Halcyon smyrnensis & White-throated Kingfisher & & & $\mathrm{AB}$ & \# & $\#$ & \# & $\#$ \\
\hline Halcyon cbloris & Collared Kingfisher & & & $\mathrm{AB}$ & $\#$ & $\#$ & $\#$ & $\#$ \\
\hline Buceros rbinoceros & Rhinoceros Hornbill & NT & II & $\mathrm{AB}$ & $\#$ & & & \\
\hline Rhyticeros undulatus & Wreathed Hornbill & & II & $\mathrm{AB}$ & $\#$ & & & \\
\hline Rhinoplax vigil J & Helmeted Hornbill & NT & I & $\mathrm{AB}$ & $\#$ & & & \\
\hline Rhipidura javanica & Pied Fantail & & & $\mathrm{AB}$ & $\#$ & & & \\
\hline Anthreptes simplex & Plain Sunbird & & & B & \# & & & \\
\hline Anthreptes singalensis & Ruby-cheeked Sunbird & & & $\mathrm{AB}$ & $\#$ & & $\#$ & \\
\hline Anthreptes malacensis & Brown-throated Sunbird & & & $\mathrm{AB}$ & \# & & & \\
\hline Cinnyris jugularis & Olive-backed Sunbird & & & $\mathrm{AB}$ & \# & & \# & \# \\
\hline Arachnothera longirostra & Little Spiderhunter & & & $\mathrm{AB}$ & $\#$ & & & \\
\hline Arachnothera affinis & Streaky-breasted Spiderhunter & & & B & $\#$ & & $\#$ & \\
\hline Anthreptes malacensis & Brown-throated Sunbird & & & $\mathrm{AB}$ & \# & & $\#$ & \\
\hline Anthreptes rhodolaema & Red-throated Sunbird & NT & & $\mathrm{AB}$ & $\#$ & & & \\
\hline Padda oryzivora & Java Sparrow & VU & II & & & & & \\
\hline Gracula religiosa & Common Hill Myna & & II & $\mathrm{AB}$ & \# & \# & & \\
\hline Dicrurus sumatranus & Sumatran Drongo & NT & & & $\#$ & & $\#$ & \# \\
\hline
\end{tabular}

${ }^{1}$ Status based on IUCN; ${ }^{2}$ CITES; ${ }^{3}$ Indonesian laws: A = Republic of Indonesia of Act no. 5/1990; B = Regulation of Indonesian Government no. 7/1999

suitable sites for nesting, resting and foraging. The number of birds that like forest edges or open areas increased, such as mynas, barbets, sparrows, bulbuls, pigeons, cuckoos, doves, prinias, white-eyes, woodpeckers and raptors.

Nonetheless, forest-edge is important as a 
buffer zone for bird diversity and as an area for the succession process of bird communities (Novarino \& Salsabila, 2005).

In the EA, Ficus trees were the food source for the frugivores. A total of 23 species of birds from 11 families were recorded in three Ficus trees that grew in the emplacement, 17 of which were recorded eating fruit. Barbets and bulbuls were common on Ficus caulocarpa and Ficus microcarpa, which have relatively small fruits. Large frugivores, such as Imperial Pigeon and hornbills, were not observed in these trees, although they were frequently seen flying overhead. Frugivore birds in the emplacement of RMP in Dolok Merangir were lower than that found in lowland tropical forest in Kuala Lompat, Malaysia (Lambert \& Marshall, 1991). Twenty nine bird species were reported as Ficus dispersal agents. Ficus forms an exclusive group within the subset of plants with bird-eaten fruit owing to the synchronized fruit ripening of each tree, the relatively short intervals between fruiting seasons, large crop sizes and different fruiting seasons in each population. These factors make Ficus an important keystone plant resource (Lambert \& Collar, 2002).

Birds are one of the most important seed dispersal agents in tropical forests (Jordano et al., 2007). Plants are food sources for animals and effective seed dispersal may reduce competition between plants and their derivatives, as well as enabling the distribution of plant species to new locations. If there are no animals to disperse the seeds, the seeds will fall on the ground and will grow around the parent tree only, affecting plant regeneration.

\section{Prominence of Protected Birds}

Bird species encountered in the four habitats were grouped based on their status according to the International Union for Conservation of Nature and Natural Resources (IUCN). Twelve near-threatened (NT) species and 2 vulnerable (VU) species we recorded. Referring to the Convention on International Trade in Endangered Species of Wild Flora and Fauna (CITES), one species was listed in Appendix
I, and 12 species were listed in Appendix II. Regarding Indonesian regulations, under Law no. $7 / 1999$, we found that 26 species were listed as protected species (Table 2).

Nine species of the 24 restricted range species were found. A restricted range species is one with a known breeding area of less than 50,000 $\mathrm{km}^{2}$ (Sujatnika, Soehartono, Crosby, \& Mardiastuti, 1995) and, by virtue of its small range, is suitable for identifying areas for conservation. It was reported that there were five Important Bird Areas (IBA) in North Sumatra and 24 restricted range species (Holmes \& Rombang, 2001).

Some noteworthy bird species that are protected under Indonesian law were encountered in North Sumatra, such as the Great Argus (Argusianus argus), Red-naped Trogon (Harpactes kasumba), Rhinoceros Hornbill (Buceros rbinoceros), Wreathed Hornbill (Rhyticeros undulatus), Blue-masked Leafbird (Chloropsis venusta), Java Sparrow (Padda oryzivora), Sumatran Drongo (Dicrurus sumatranus), Finsch's Bulbul (Criniger finschii), Large Green Pigeon (Treron capeller), Blue-crowned Hanging Parrot (Loriculus galgulus), Black-bellied Malkoha (Rhopodytes diardi), Volcano Swiftlet (Collocalia vulcanorum), Barn Owl (Tyto alba), Buffy Fish Owl (Ketupa ketupu), Collared Owlet (Galucidium brodier), Helmeted Hornbill (Rhinoplax vigi), Buff-necked Woodpecker (Meiglyptes tukki), Green Broadbill (Calyptomena viridis) and the Common Hill Myna (Gracula religiosa).

A number of raptor species were also found in the area, such as the Brahminy Kite (Haliastur indus), White-bellied Sea Eagle (Haliaeetus leucogaster), Black Eagle (Ictinaetus malayensis), Crested Hawk-Eagle (Spizaetus cirrhatus), Blyth's Hawk-Eagle (Spizaetus alboniger) and the Crested Serpent Eagle (Spilornis cheela). All these raptors are protected under Indonesian law. Moreover, the high number of raptor birds in this area implies it is a part of their home range. Raptors are known to have a wide home range compared to other bird species. Their prey includes various mammals and reptiles, including squirrels, rats and lizards. The study 
Table 3. Number of protected bird species in four habitat types

\begin{tabular}{lccc}
\hline & Habitats & Status \\
\cline { 2 - 4 } & IUCN & CITES & UU/PP RI \\
\hline NF & 9 & 13 & 26 \\
RAF & 1 & 3 & 8 \\
RMP & 0 & 4 & 5 \\
EA & 1 & 3 & 5 \\
\hline
\end{tabular}

${ }^{1}$ Status based on IUCN; ${ }^{2}$ CITES; ${ }^{3}$ Indonesian laws: A $=$ Republic of Indonesia Act no. 5/1990; B = Regulation of Indonesian Government no. 7/1999.

area in North Sumatra may provide significant amounts of food. Some bird species (predator and raptor guild types) benefit to agriculture. Predators, like eagles (family: Accipitridae) and owls (family: Strigidae) prey rodents, which are pests to crops and tree crops, such as oil palm. However, there are very few studies of the potential relationship of birds in either natural or agricultural ecosystems.

Number of protected birds based on IUCN status, CITES, and Indonesian regulations are issummarized in Table 3. High number of protected bird species found in NF, consecutively followed by RAF, RMP and EA. Forests provide suitable habitat for protected bird species, which can not be replaced by any other habitats.

\section{Implications for Conservation}

Forest per se is not sufficient to protect bird diversity in a given habitat. Each species of birds occupies a particular habitat in accordance with its needs and plays a certain role in the environment (Mulyani, 1985).The diversity of bird species is affected by a decline in the carrying capacity of the habitat. Changes in vegetation structure and species composition in disturbed forests and cleared land affect on richness of bird species, thus altering composition of bird species. Habitats fragmentation in the study area consisted of patchy forest, RAFs and RMPs which are composed of different species. Forest has the highest index diversity compared with RAF and RMP (Ningsih, Rahayu, \& Tata, 2011). Differences in tree composition in the three habitats of North Sumatra affected bird species richness, diversity and composition. Gonzalez-Oreja et al. (2012) reported there is a positive correlation between tree diversity and bird diversity.

Rapid land-use change and high deforestation are threatening the diversity and conservation status of birds (Rittenhouse et al., 2010). Forest cover in Aek Tarum study area has lost dramatically from 45018 ha $(56.03 \%)$ in 1970 to 10220 ha $(12.80 \%)$ in 2010 (Said, Ekadinata, \& Widayati, 2011). Habitat fragmentation will cause the loss of specialist types (interior species) which includes terrestrial birds. Another consequence of the habitat fragmentation is the presence of edge effects. The area will be occupied by the edge of the bird species that are at risk of ecological disturbance or interference from outside. Degraded and fragmentation areas will impact on the dynamics and meta-population (Wiens, 1989; Lunberg \& Moberg, 2003). Our observation showed that bird species in the study area have different tolerances of fragmentation and canopy openings. Some, such as hornbills and woodpeckers, were only encountered in forest habitat, being very sensitive to habitat change. Other species have a wider range of adaptive abilities, such as Pycnonotidae (bulbul), Columbidae (pigeon and dove) and Sylvidae (prinias and wabler), which were found across different land uses.

Implications of forest fragmentation caused three important processes, namely extinction, migration and colonization. Fragmented region will lead to solving the sub-sub-populations and reduces movement (migration) types among 
sub-populations thereby increasing the risk of extinction. Separation between sub-populations will decrease colonization opportunities for regeneration (Wiens, 1989; André, 1994). Birds with large territorial requirements, such as raptors, apparently are sensitive to habitat fragmentation.

Birds act as mobile conduits, transferring energy among ecosystems, and contribute to ecosystem functions and resilience with their foraging. Bird-plant interactions like pollination and seed dispersal have a high impact on ecosystems (Lunberg \& Moberg, 2003). The pollination process of some tree species is assisted by birds. Nectarivore birds (family: Nectariniidae) that only consume nectar, pollinate some trees species and were encountered in both forests and RAF, but not found in RMP. Four species of nectarivore were found in both forest and RAF, namely Anthreptes singalensis, Cinnyris jugularis, Arachnothera affinis and Anthreptes malacensis.

Birds disperse seeds through fruit consumption. Frugivore birds (family: Columbidae and Sturnidae) that only consume fruit, were encountered in the four habitats. Birds disperse seeds of many woody plant species of value to humans for timber, medicine, food and other uses. A number of frugivore birds and those who combine frugivore with other food were encountered in forests, however far fewer frugivores were found in RAF and RMPs.

Large frugivore birds, such as Bucerotidae, were not found in RAF and RMP, as they are very susceptible to anthropogenic and environmental change. Larger fruits require larger birds to carry and disperse the fruit at a distance from the mother trees. A lower density of frugivores birds may result in seedlings being concentrated under the mother trees and not widely dispersed (Wenny et al., 2011), which in turn may decrease tree diversity in the ecosystems.

Birds also contribute to the nutrient cycling in the ecosystems. Aquatic and marine birds produce guano, which is a valuable phosphorous fertilizer (Wenny et al., 2011). Aquatic birds belonging to the piscivore type that consume fish were found in the forest only (Ardea spp. and Egretta garzetta). The landscape of the study area consisted of hilly mountains, valleys, and lowlands along the rivershed of Aek Tarum and Sigura-gura of North Sumatra. Forest area concentrated at the hilly mountains (Asahan and Bukit Barisan landscape) for birds' habitat of mountain species up to $700 \mathrm{~m}$ asl level such as Silver-breasted Broadbill (Serilophus lunatus), Long-tailed Broadbill (Psarisomus dalhousiae) and Fire-tufted Barbet (Psilopogon pyrolophus). Although piscivores are considered predators, they also contribute to nutrient cycling in their habitats. All birds contribute to maintaining the equilibrium of the food chain in the ecosystems.

When forest habitat is degraded, RAFs become an alternative sanctuary where birds can nest and forage. The vegetation in RAFs provides good carrying capacity for bird diversity. To improve biodiversity in the area it is recommended to preserve intermediary regions, such as along riverbanks and main roads in the RMPs. An intermediary region could be a corridor between one region and another along the border of the RMPs. In such places, planting rubber trees mixed with fruit trees, such as Ficus, that could provide habitat for birds is recommended.

\section{CONCLUSION}

Natural forests have the highest bird diversity compared with RAFs, RMPs and EAs. Changing natural ecosystems to man-made ecosystems affected bird species' composition and numbers. Habitat loss reduced bird composition, and birds with specialist roles have the highest risk of extinction. Compared with RAFs, RMPs are less suitable for all bird species. Birds provide many ecosystem services, especially regulating and supporting services, which directly and indirectly benefit humans. Efforts to conserve habitats and bird populations will maintain the diverse services provided by ecosystems, thus contributing to human well-being. 


\section{ACKNOWLEDGEMENT}

The authors gratefully acknowledge the Bridgestone Corporation and PT. Bridgestone Sumatra Rubber Estate (BSRE) for financial and logistical support during the research project "Towards biodiverse rubber plantations: a Quick biodiversity survey in Bridgestone Sumatra's Rubber Estate Plantation" to the World Agroforestry Centre (ICRAF) Southeast Asia Regional Office. The Forest Research Institute of Aek Nauli is acknowledged for giving permission to conduct our research in the forest research area. We thank Prof. Ani Mardiastuti and Dr. Jarwadi Hernowo for invaluable inputs and comments to the manuscript and one anonymous reviewer of language. We also thank Andrew J. Warner and Cassandra Graham for improving the language.

\section{REFERENCES}

Act of the Republic of Indonesia No. 5 of 1990 Concerning Conservation of Natural Resources and Their Ecosystems (in Bahasa Indonesia) (1990). Indonesia

Andrén, H. (1994). Effects of habitat fragmentation on birds and mammals in landscapes with different proportions of suitable habitat: A review. Oikos, 71(3), 355-366.

Andrew, P. (1992). The birds of Indonesia-a checklist (Peter's Sequence). Jakarta: Indonesian Ornithological Society.

Aratrakorn, S., Thunhikorn, S., \& Donald, P.F. (2006). Changes in bird communities following conversion of lowland forest to oil palm and rubber plantations in southern Thailand. Bird Conservation International, 16(1), 71-82. doi:10.1017/S095927090600006

Baker, J., French, K., \& Whelan, R. J. (2002). The edge effect and ecotonal species: Bird communities across a natural edge in southeastern Australia. Ecology, 83, 3048-3059.

CITES. (2012). Convention on International Trade in Endangered species of Wild Fauna and Flora. Apendices I, II and III. CITES and UNEP. Retrieved from http://www.cites.org/eng/ app/2012/E-2012-09-25.pdf

Danielsen, F., \& Heegard, M. (1995). Impact of logging and plantation development on species diversity: a case study from Sumatra. In Ø. Sandbukt (Ed.), Management of tropical forests: towards an integrated perspective (pp. 7392). Oslo: Centre for Development and the Environment, University Oslo.

Ekadinata, A., \& Vincent, G. (2011). Rubber agroforests in a changing landscape: analysis of land use/cover trajectories in Bungo District, Indonesia. Forests, Trees and Livelihoods, 20, 3-14.

Fitri, L., \& Ford, H. A. (2003). Breeding biology of Hooded Robins Melanodryas cucullata in New England, New South Wales. Corella, 27, 6874.

González-Oreja, J. A., Barillas-Gómez, A. L., Bonache-Regidor, C., Buzo-Franco, D., García-Guzmán, J., \& Hernández-Santín, L. (2012). Does habitat heterogeneity affect bird community structure in urban parks? In C. A. Lepczyk \& P. S. Warren (Eds.), Urban bird ecology and conservation (Studies in Avian Biology No. 45). (pp. 1-16). Berkeley, CA: University of California Press. Retrieved from http://www. ucpress.edu/content/ancillaries/12112/ lepczyk_special_topic_a.pdf

Goverment Regulation of Republic Indonesia No. 7 of 1999 concerning Preservation of plants and animals (in Bahasa Indonesia) (1999). Indonesia

Hernowo, J. B., Soekmadi, R., \& Ekarelawan. (1991). A study of wildlife in IPB Campus Darmaga Wildlife. Media Conservation, 3(2), 43-65.

Holmes, D. A., \& Rombang, W. M. (2001). Important bird area: Sumatra. Bogor: Birdlife International/PHKA.

International Union for Conservation of Nature (IUCN). (2012). The IUCN Red List of Threatened Species. Gland, Switzerland: International Union for Conservation of Nature (IUCN). Retrieved from www. iucnredlist.org

Jihad. (2009). The diversity types of birds at agroforestry and primary forest habitat in the Region of Sibulan-bulan, Batang Toru, North Sumatra (Thesis) (in Bahasa Indonesia). Universitas Negeri Jakarta.

Jordano, P., Godoy, J. A., \& Garcia-Castano, J. L. (2007). Differential contribution of frugivores to complex seed dispersal patterns. Proceedings of the National Academy of Sciences US A, 104(9), 3278-3282. doi:10.1017/ S095927090600006

Joshi, L., Wibawa, G., Vincent, G., D., B., Akiefnawati, R., Manurung, G., \& van Noordwijk, M. (2002). Complex rubber agroforestry: challenge for development. Bogor: International Centre for Research in Agroforestry (ICRAF).

Karr, J. R., Schemske, D. S., \& Brokaw, N. V. L. 
(1983). Temporal variation in the understorey bird community of tropical forest. In E. J. Leight (Ed.), The Ecology of a Tropical Forest Seasonal Rhythms and Long Term Changes (pp. 441-454). Oxford, UK: Oxford University Press.

King, B., Woodcock, M., \& Dickinson, E. C. (1975). Field guide to the birds of South East Asia. London: Harper Collins Publishers.

Krebs, C. J. (1999). Ecological methodology (2 ${ }^{\text {nd }}$ ed.). Canada: Addison-Welsey Educational Publiser, Inc.

Lambert, F. R., \& Collar, N. J. (2002). The future for Sundaic lowland forest birds: Longterm effects of commercial logging and fragmentation. Forktail, 18, 127-146.

Lambert, F. R., \& Marshall, A. G. (1991). Keystone characteristics of bird-dispersed Ficus in a Malaysian lowland rain forest. JournalEcolology, 79, 793-809.

Lane, V. R., Miller, K. V., Castleberry, S. B., Cooper, R. J., Miller, D. A., Wigley, T. B., ... Mihako, R. L. (2011). Bird community reponses to a gradient of site preparation intensities in pine plantation in the coastal plain of North Carolina. Forest Ecology and Management, 262, 1668-1678.

Laumonier, Y., Uryu, Y., Stüwe, M., Budiman, A., Setiadi, B., \& Hadian, O. (2010) (2010). Ecofloristic sector and deforestation threats in Sumatra: identifying new conservation area network priorities for ecosystem-based land use planning. Biodiversity and Conservation, 1, 1153-1174.

Lunberg, J., \& Moberg, F. (2003). Mobile link organisms and ecosystem functioning: Implications for ecosystem resilience and management. Ecosystems, 6, 87-98.

MacKinnon, J., \& Phillips, K. (1993). Field guide to the birds of Sumatra, Borneo, Java and Bali (The Greater Sunda Islands). Oxford, UK: Oxford University Press.

MacKinnon, J., Phillips, K., \& van Balen, B. (1998). A field guide of the birds of Borneo, Sumatra, Java and Bali. Bogor: Puslitbang Biologi LIPI Birdlife International Indonesia Program.

Magurran, A. E. (1988). Ecological diversity and its measurement. Cambridge: Cambridge University Press.

Marle, J. G. M., \& Marle, V. (1988). The birds of sumatra: an annotated checklist (B.O.U. Check-list No. 10). British Ornithologists Union, UK.

McNeely, J. A. (1988). Economics and biological diversity: developing and using economic incentives to conserve biological resources. Gland, Switzerland: IUCN.

Mulyani, Y. A. (1985). Study of the diversity of bird species on the campus of IPB Dramaga [Unpublished Thesis] (in Bahasa Indonesia). Bogor Agricultural University, Bogor.

Nair, P. K. R. \& Garrity, D. P. (Ed.). (2012). Agroforestry: The future of global land use. The Netherland: Springer.

Ningsih, H., Rahayu, S., \& Tata, H. L. (2011). Compariosn of floristic composition and diversity in bridgestone rubber plantations and their surroundings. In H. L. Tata (Ed.), Recognizing biodiversity in rubber plantations (pp. 35-50). Bogor: World Agroforestry Centre (ICRAF) Southeast Asia Regional Office. Retrieved from http://www. worldagroforestry.org/sea/Publications / files/report/RP0277-11.PDF.

Novarino, W., \& Salsabila, A. (2005). Type of bird diversity in the concession area PT Nusa Lease Timber Corp dan PT Sestra II. Jurnal Biologica, 1(9), 11-21.

O’Brien, T. G., \& Kinnaird, M. F. (1996). Birds and mammals of the Bukit Barisan Selatan national Park, Sumatra, Indonesia. Oryx, 30(3), 207-217.

Odum, E. P. (1971). Fundamental of ecology (3 $3^{\text {rd }}$ ed.). Philladelphia: W.B. Saunders Co.

Prawiradilaga, D. M., Astuti, D., Marakarmah, A., Wijamukti, S., \& Kundarmasno, A. (2002). Monitoring the bird community at Gunung Kendeng-Gunung Halimun National Park (Part A). In S. Kahono, T. Okayama, \& A. J. Arief (Eds.), Biodiversity of the last submontane tropical rain forest in Java: Gunung Halimun National Park (pp. 4-13). Bogor: Research and Conservation of Biodiversity in Indonesia.

Rittenhouse, C. D., Pidgeon, A. M., Albright, T. P., Culbert, P. D., Clayton, M. K., Flather, S. H., ... Radeloff, V. C. (2010). Conservation of forest birds: Evidence of a sift baseline in community structure. PloS ONE, 5(8), 1-9. doi:10.1371/journal.pone.0011938

Said, Z., Ekadinata, A., \& Widayati, A. (2011). Landuse and land-cover changes and trajectories in Dolok Merangir and Aek Tarum. In H. L. Tata (Ed.), Recognizing biodiversity in rubber plantations (pp. 16-36). Bogor, Indonesia: World Agroforestry Centre (ICRAF) Southeast Asia Regional Office. Retrieved from http:/ /www. worldagroforestry.org/sea/Publications / files/report/RP0277-11.PDF

Sirait, M. A. (2007). Field test of the Rapid Land Tenure Assessment (RATA) on the Batang Toru Watershed, North Sumatra. Working Paper. Bogor, Indonesia: World Agroforesry Centre (ICRAF) South East Asia Regional Programme. 
Sujatnika, J. P., Soehartono, T. R., Crosby, M. J., \& Mardiastuti, A. (1995). Conserving Indonesian biodiversity : the endemic bird area approach. Jakarta: PHPA/Birdlife International - Indonesia Program.

Sukmantoro, W., Irham, M., Novarino, W., Hasundungan, F., Kemp, N., \& Muchtar, M. (2007). List of birds Indonesia No. 2. Bogor, Indonesia: Indonesian Ornithologist Union.

Tata, H. L., Nurhariyanto, Prasetyo, P. N., Jihad, Joshi, L., \& Martini, E. (2013). Quick biodiversity survey (QBSur). In M. Van Noordwijk, B. Lusiana, S. Dewi, \& D. Wulandari (Eds.), Negotiation-support toolkit for learning landscapes (pp. 139-142). Bogor: World Agrofroestry Centre Southeast Asia Regional Program. Retrieved from http://www.asb.cgiar.org/ book/negotiation-support-toolkit-learninglandscapes

Tata, H. L., Van Noordwijk, M., \& Werger, M. J. (2008). Trees and regeneration in rubber agroforests and other forest-derived vegetation in Jambi (Sumatra, Indonesia). Journal of Forestry Research, 5(1), 1-20.

van Noordwijk, M., Tata, H. L., Xu, J., Dewi, S., \& Minang, P. (2012). Segregate or integrate for multifunctionality and sustained change through rubber-based agroforestry in
Indonesia and China. In P. K. . R. Nair \& D. P. Garrity (Eds.), Agroforestry: The Future of global land use (pp. 69-104). The Netherlands: Springer.

Warmke, H. E. (1952). Studies on natural pollination of Hevea brasiliensis in Brazil. Science. Science, 116(3018), 474-475.

Welty, J. C. (1982). The life of birds ( $3^{\text {rd }}$ ed.). Philladelphia: Saunders College Publishing.

Wenny, D. G., DeVault, T. L., Johnson, M. D., Kelly, D., Sekercioglu, C. H. Tomback, D. F., \& Whelan, C. J. (2011). The need to quantify ecosystem services provided by birds. The Auk, 128(1), 1-14.

Wiens, J. A. (1989). The Ecology of bird communities. Cambridge, U.K.: Cambridge University Press.

World Agroforestry Centre (ICRAF). (2011). Accountability and local level initiative to reduce emission from deforestation and degradation in Indonesia (ALLREDDI Final Report). Bogor: World Agroforestry CentreICRAF.

Yoza, D. (2000). Oilpalm plantation impact on biodiversity bird in PT Ramajaya Pramukti Plantation Area District Kampar in Rian Province [Thesis]. Bogor Agricultural University, Bogor. 
Appendix 1. List of birds found in different habitat types in North Sumatra

\begin{tabular}{|c|c|c|c|c|c|c|c|c|c|c|}
\hline \multirow{2}{*}{ Scientific Name ${ }^{1}$} & \multirow[b]{2}{*}{ English Name } & \multirow{2}{*}{ Guild $^{2}$} & \multicolumn{3}{|c|}{ Status $^{3}$} & \multirow[t]{2}{*}{$\mathbf{P}$} & \multicolumn{4}{|c|}{ Habitat } \\
\hline & & & IUCN & CITES $^{4}$ & $\begin{array}{l}\text { UU/ } \\
\text { PP RI }^{5}\end{array}$ & & $\mathrm{NF}$ & RMP & RAF & EA \\
\hline \multicolumn{11}{|l|}{ Ardeidae } \\
\hline Ardea cinerea & Grey Heron & $\mathrm{P}$ & & & & $\mathrm{s}$ & \# & & & \# \\
\hline Ardea purpurea & Purple Heron & $\mathrm{P}$ & & & & $\mathrm{s}$ & \# & & & \# \\
\hline Ardea alba & Great Egret & $\mathrm{P}$ & & & $\mathrm{AB}$ & $\mathrm{s}$ & \# & & & \\
\hline $\begin{array}{l}\text { Egretta garzetta } \\
\text { Accipitridae }\end{array}$ & Little Egret & $\mathrm{P}$ & & & $\mathrm{AB}$ & $\mathrm{s}$ & \# & & & \\
\hline Haliastur indus & Brahminy Kite & $\mathrm{R}$ & & II & $\mathrm{AB}$ & $\mathrm{s}$ & \# & & & \\
\hline Haliaeetus leucogaster & White-bellied Sea Eagle & $\mathrm{R}$ & & II & $A B$ & $\mathrm{~s}$ & \# & & & \\
\hline Ictinaetus malayensis & Black Eagle & $\mathrm{R}$ & & II & $\mathrm{AB}$ & $\mathrm{s}$ & \# & & \# & \# \\
\hline Spizaetus cirrhatus & Crested Hawk-Eagle & $\mathrm{R}$ & & II & $\mathrm{AB}$ & $\mathrm{s}$ & \# & & & \# \\
\hline Spizaetus alboniger & Blyth's Hawk-Eagle & $\mathrm{R}$ & & II & $\mathrm{AB}$ & $\mathrm{s}$ & \# & & & \\
\hline Spilornis cheela & Crested Serpent Eagle & $\mathrm{R}$ & & II & $A B$ & & \# & \# & \# & \\
\hline Accipiter virgatus & Besra & $\mathrm{R}$ & & II & $\mathrm{AB}$ & $\mathrm{s}$ & & \# & & \\
\hline \multicolumn{11}{|l|}{ Phasianidae } \\
\hline Lophura inornata & Salvadori's Pheasant & TIF & & & & $h+r$ & \# & & & \\
\hline Gallus gallus & Red Junglefowl & TIF & & & & $h+r$ & \# & & & \\
\hline Argusianus argus & Great Argus & TIF & NT & II & $\mathrm{AB}$ & $\mathrm{h}$ & \# & & & \\
\hline Turnicidae & & & & & & & & & & \\
\hline $\begin{array}{l}\text { Turnix suscitator } \\
\text { Rallidae }\end{array}$ & Barred Buttonquail & TIF & & & & $\mathrm{s}$ & \# & & & \\
\hline $\begin{array}{l}\text { Amaurornis } \\
\text { phoenicurus }\end{array}$ & White-breasted Waterhen & TIF & & & & s & \# & & & \\
\hline \multicolumn{11}{|l|}{$\begin{array}{l}\text { Phoenicurus } \\
\text { Columbidae }\end{array}$} \\
\hline Treron capellei & Large Green Pigeon & $\mathrm{AF}$ & $\mathrm{VU}$ & & & $\mathrm{s}$ & \# & & & \\
\hline Treron olax & Little Green Pigeon & $\mathrm{AF}$ & & & & $\mathrm{s}$ & \# & & & \\
\hline Treron vernans & Pink-necked Green Pigeon & $\mathrm{AF}$ & & & & $\mathrm{s}$ & \# & \# & \# & \# \\
\hline Macropygia ruficeps & Little Cuckoo Dove & $\mathrm{AF}$ & & & & $\mathrm{s}+\mathrm{h}$ & \# & & & \\
\hline Streptopelia chinensis & Spotted Dove & $\mathrm{AF}$ & & & & $\mathrm{s}+\mathrm{h}$ & \# & \# & \# & \# \\
\hline Geopelia striata & Zebra Dove & $\mathrm{AF}$ & & & & & & \# & \# & \\
\hline Psittacidae & & & & & & & & & & \\
\hline Loriculus galgulus & Blue-crowned Hanging Parrot & $\mathrm{AF}$ & & II & & s & $\#$ & & $\#$ & \\
\hline Cuculus saturatus & Oriental Cuckoo & AFGI & & & & s & & \# & & \\
\hline Cacomantis sepulcralis & Rusty-breasted Cuckoo & AFGI & & & & $\mathrm{h}$ & & & & \# \\
\hline Surniculus lugubris & Asian Drongo-Cuckoo & AFGI & & & & $\mathrm{h}$ & \# & \# & & \\
\hline Eudynamys scolopaceus & Asian Koel & AFGI & & & & $\mathrm{h}$ & \# & & & \\
\hline Rhopodytes diardi & Black-bellied Malkoha & AFGI & NT & & & s & \# & & & \\
\hline Rhinortha chlorophaeus & Raffles's Malkoha & AFGI & & & & $\mathrm{s}$ & \# & & & \\
\hline Centropus sinensis & Greater Coucal & TI & & & & $\mathrm{s}+\mathrm{h}$ & \# & & & \\
\hline Centropus bengalensis & Lesser Coucal & TI & & & & $\mathrm{h}$ & \# & \# & \# & \\
\hline Tytonidae & & & & & & & & & & \\
\hline Tyto alba & Barn Owl & $\mathrm{NP}$ & & II & & s & & & & \# \\
\hline $\begin{array}{l}\text { Strigidae } \\
\quad \text { Ketupa ketupu }\end{array}$ & Buffy Fish-Owl & $\mathrm{NP}$ & & II & & & & & & \\
\hline $\begin{array}{l}\text { Ketupa ketupu } \\
\text { Glaucidium brodiei }\end{array}$ & Collared Owlet & NP & & II & & $\begin{array}{l}\mathrm{s} \\
\mathrm{s}\end{array}$ & \# & \# & & \\
\hline Apodidae & & & & & & & & & & \\
\hline Collocalia vulcanorum & Volcano Swiftlet & $\mathrm{AI}$ & NT & & & $\mathrm{s}$ & \# & & & \\
\hline Collocalia fuciphagus & Edible-nest Swiftlet & $\mathrm{AI}$ & & & & $\mathrm{s}$ & & & & \# \\
\hline Collocalia esculenta & Glossy Swiftlet & $\mathrm{AI}$ & & & & $\mathrm{s}$ & \# & \# & \# & \\
\hline Collocalia linchi & Cave Swiftlet & AI & & & & $\mathrm{s}$ & & & \# & \\
\hline Hirundapus caudacutus & White-throated Needletail & AI & & & & $\mathrm{s}$ & \# & & & \\
\hline Apus nipalensis & House Swift & AI & & & & $\mathrm{s}$ & \# & & \# & \# \\
\hline Hemiprocnidae & & & & & & & & & & \\
\hline Hemiprocne comata & Whiskered Treeswift & SI & & & & $\mathrm{s}$ & \# & & & \# \\
\hline $\begin{array}{l}\text { Trogonidae } \\
\text { Trdactes } k a s u m b a\end{array}$ & & & & & & & & & & \\
\hline $\begin{array}{l}\text { Harpactes kasumba } \\
\text { Alcedinidae }\end{array}$ & Red-naped Trogon & SSGI & NT & & $\mathrm{AB}$ & $s+r$ & \# & & & \\
\hline $\begin{array}{l}\text { Alcedinidae } \\
\text { Alcedo meninting }\end{array}$ & Blue-eared Kingfisher & MIP & & & $\mathrm{AB}$ & $\mathrm{s}$ & \# & & & \\
\hline Halcyon smyrnensis & White-throated Kingfisher & MIP & & & $\mathrm{AB}$ & $\mathrm{s}$ & \# & \# & \# & \# \\
\hline Halcyon chloris & Collared Kingfisher & MIP & & & $A B$ & $\mathrm{~s}$ & \# & \# & \# & \# \\
\hline Meropidae & & & & & & & & & & \\
\hline Merops leschenaulti & Chestnut-headed Bee-eater & SI & & & & $\mathrm{s}$ & & & \# & \\
\hline Merops viridis & Blue-throated Bee-eater & SI & & & & $\mathrm{s}$ & \# & \# & & \# \\
\hline Bucerotidae & & & & & & & & & & \\
\hline Buceros rhinoceros & Rhinoceros Hornbill & AFP & NT & II & $\mathrm{AB}$ & $\mathrm{h}$ & \# & & & \\
\hline Rhyticeros undulatus & Wreathed Hornbill & AFP & & II & $A B$ & $s+h$ & \# & & & \\
\hline Rhinoplax vigil J & Helmeted Hornbill & AFP & NT & I & $A B$ & $h+r$ & \# & & & \\
\hline Capitonidae & & & & & & & & & & \\
\hline Psilopogon pyrolophus & Fire-tufted Barbet & AFP & & & & $\mathrm{s}$ & \# & & & \\
\hline Megalaima chrysopogon & Golden-whiskered Barbet & AFP & & & & $\mathrm{s}$ & \# & & & \\
\hline Megalaima oorti & Black-browed Barbet & AFP & & & & $\mathrm{s}+\mathrm{h}$ & \# & & & \\
\hline Megalaima & Coppersmith Barbet & AFP & & & & $\mathrm{s}+\mathrm{h}$ & $\#$ & & \# & $\#$ \\
\hline haemacephala & & & & & & & & & & \\
\hline $\begin{array}{l}\text { Calorhamphus } \\
\text { fuliginosus }\end{array}$ & Brown Barbet & AFP & & & & $\mathrm{s}$ & & & \# & \\
\hline
\end{tabular}




\begin{tabular}{|c|c|c|c|c|c|c|c|c|c|c|}
\hline \multirow[b]{2}{*}{ Scientific Name ${ }^{1}$} & \multirow[b]{2}{*}{ English Name } & \multirow[b]{2}{*}{ Guild $^{2}$} & \multicolumn{3}{|c|}{ Status $^{3}$} & \multirow[t]{2}{*}{$\mathbf{P}$} & & $\mathrm{Hal}$ & & \\
\hline & & & IUCN & CITES $^{4}$ & $\begin{array}{c}\mathrm{UU} / \\
\text { PP RI }^{5}\end{array}$ & & NF & RMP & RAF & EA \\
\hline Picidae & & & & & & & & & & \\
\hline Picumnus innominatus & Speckled Piculet & BGI & & & & $\mathrm{s}$ & & & & \# \\
\hline Picus flavinucha & Greater Yellownape & BGI & & & & $\mathrm{s}$ & \# & & & \\
\hline Dinopium javanense & Common Goldenback & BGI & & & & $\mathrm{s}$ & \# & & & \\
\hline Meiglyptes tukki & Buff-necked Woodpecker & BGI & NT & & & s & \# & & & \\
\hline Dendrocopos moluccensis & Sunda Pygmy Woodpecker & BGI & & & & $\mathrm{s}$ & \# & \# & \# & \# \\
\hline Reinwardtipicus validus & Orange-backed Woodpecker & BGI & & & & s & \# & & & \\
\hline Eurylaimidae $P$ ( & & & & & & & & & & \\
\hline Serilophus lunatus & Silver-breasted Broadbill & SSGI & & & & s & \# & & & \\
\hline Psarisomus dalhousiae & Long-tailed Broadbill & SSGI & & & & $\mathrm{h}$ & \# & & & \\
\hline Calyptomena viridis & Green Broadbill & SSGI & NT & & & $\mathrm{h}$ & $\#$ & & & \\
\hline Hirundinidae & & & & & & & & & & \\
\hline Delichon dasypus & Asian House Martin & AFGI & & & & $\mathrm{s}$ & \# & \# & \# & \# \\
\hline Campephagidae & & & & & & & & & & \\
\hline Pericrocotus divaricatus & Ashy Minivet & AFGI & & & & s & \# & & & \\
\hline Pericrocotus flammeus & Scarlet Minivet & AFGI & & & & $\mathrm{s}$ & \# & & & \\
\hline Hemipus picatus & Bar-winged Flycatcher-shrike & AFGI & & & & $\mathrm{s}$ & \# & & & \\
\hline Aegithinidae & & & & & & & & & & \\
\hline Aegithina tiphia & Common Iora & AFGI & & & & $\mathrm{s}+\mathrm{h}$ & \# & & \# & \# \\
\hline Chloropseidae & & & & & & & & & & \\
\hline Chloropsis venusta & Blue-masked Leafbird & NIF & NT & & & $\mathrm{s}$ & \# & & & \\
\hline Chloropsis sonnerati & Greater Green Leafbird & NIF & & & & $\mathrm{s}$ & \# & & & \\
\hline Pycnonotidae & & & & & & & & & & \\
\hline Pycnonotus atriceps & Black-headed Bulbul & AFGIF & & & & $\mathrm{s}$ & \# & & & \\
\hline Pycnonotus melanicterus & Black-crested Bulbul & AFGIF & & & & s & \# & & \# & \\
\hline Pycnonotus aurigaster & Sooty-headed Bulbul & AFGIF & & & & s & \# & \# & \# & \# \\
\hline Pycnonotus bimaculatus & Orange-spotted Bulbul & AFGIF & & & & $\mathrm{s}$ & \# & & & \\
\hline Pycnonotus goiavier & Yellow-vented Bulbul & AFGIF & & & & s & \# & \# & \# & \# \\
\hline Pycnonotus simplex & Cream-vented Bulbul & AFGIF & & & & $\mathrm{s}$ & \# & & \# & \\
\hline $\begin{array}{l}\text { Pycnonotus } \\
\text { erythropthalmos }\end{array}$ & Spectacled Bulbul & AFGIF & & & & s & \# & & & \\
\hline $\begin{array}{l}\text { Criniger finschii } \\
\text { Laniidae }\end{array}$ & Finsch's Bulbul & AFGIF & NT & & & $\mathrm{s}$ & \# & & & \\
\hline Lanius tigrinus & Tiger Shrike & SI & & & & s & \# & \# & & \\
\hline Lanius cristatus & Brown Shrike & SI & & & & s & \# & & & \\
\hline Lanius schach & Long-tailed Shrike & SI & & & & s & \# & & \# & \# \\
\hline Turdidae & & & & & & & & & & \\
\hline Brachypteryx montana & White-browed Shortwing & AFGI & & & & $\mathrm{h}+\mathrm{s}$ & & & \# & \\
\hline Copsychus saularis & Oriental Magpie-robin & AFGI & & & & $\mathrm{s}$ & \# & \# & \# & \# \\
\hline Copsychus malabaricus & White-rumped Shama & AFGI & & & & $\mathrm{h}+\mathrm{s}$ & \# & & \# & \\
\hline Timaliidae & & & & & & & & & & \\
\hline Malacocincla sepiarium & Horsfield's Babbler & AFGI & & & & $\mathrm{h}$ & \# & & & \\
\hline Malacocincla abboti & Abbott's Babbler & AFGI & & & & $\mathrm{h}$ & \# & & & \\
\hline Stachyris rufifrons & Rufous-fronted Babbler & AFGI & & & & $\mathrm{h}$ & \# & & & \\
\hline Macronous gularis & Striped Tit-Babbler & AFGI & & & & $\mathrm{h}$ & \# & & & \\
\hline Garrulax leucolophus & White-crested & AFGI & & & & $\mathrm{h}+\mathrm{r}$ & \# & & & \\
\hline & Laughingthrush & & & & & & & & & \\
\hline Garrulax lugubris & Black Laughingthrush & AFGI & & & & $h+r$ & \# & & & \\
\hline Sylviidae & & & & & & & & & & \\
\hline Cettia vulcania & Sunda Bush-warbler & AFGI & & & & $\mathrm{h}$ & \# & & \# & \\
\hline Prinia atrogularis & Hill Prinia & AFGI & & & & s & \# & \# & \# & \\
\hline Prinia familiaris & Bar-winged Prinia & AFGI & & & & s & \# & & \# & \\
\hline Orthotomus cuculatus & Mountain Tailorbird & AFGI & & & & s & \# & & & \\
\hline Orthotomus sutorius & Common Tailorbird & AFGI & & & & $\mathrm{s}$ & \# & \# & \# & \\
\hline Orthotomus atrogularis & Dark-necked Tailorbird & AFGI & & & & s & \# & & & \\
\hline Orthotomus sericeus & Rufous-tailed Tailorbird & AFGI & & & & $\mathrm{s}$ & \# & & & \\
\hline Orthotomus ruficeps & Ashy Tailorbird & AFGI & & & & s & \# & & & \# \\
\hline Phylloscopus inornatus & Yellow-browed Warbler & AFGI & & & & s & \# & \# & \# & \\
\hline Phylloscopus borealis & Arctic Warbler & AFGI & & & & $\mathrm{s}$ & \# & \# & & \\
\hline Phylloscopus trivirgatus & Mountain Leaf Warbler & AFGI & & & & s & & & & \\
\hline Seicercus grammiceps & Sunda Warbler & AFGI & & & & $\mathrm{s}$ & $\#$ & & & \\
\hline Abroscopus superciliaris & Yellow-bellied Warbler & AFGI & & & & s & \# & & \# & \# \\
\hline Muscicapidae & & & & & & & & & & \\
\hline Saxicola caprata & Pied Bush Chat & SI & & & & s & \# & & \# & \\
\hline Muscicapa dauurica & Asian Brown Flycatcher & SI & & & & s & \# & & & \\
\hline Ficedula hyperythra & Snowy-browed Flycatcher & SI & & & & s & \# & & & \\
\hline Ficedula westermanni & Little Pied Flycatcher & SI & & & & $\mathrm{s}$ & \# & & \# & \\
\hline Acanthizidae & & & & & & & & & & \\
\hline Gerygone sulphurea & Golden-bellied Geryone & SI & & & & $\mathrm{s}+\mathrm{h}$ & \# & \# & & \# \\
\hline Rhipiduridae & & & & & & & & & & \\
\hline Rhipidura javanica & Pied Fantail & SI & & & $\mathrm{AB}$ & $\mathrm{h}$ & \# & & & \\
\hline Paridae & & & & & & & & & & \\
\hline Parus major & Great Tit & SI & & & & $\mathrm{s}$ & & & & \\
\hline Dicaeidae & & & & & & & & & & \\
\hline Dicaeum sanguinolentum & $\begin{array}{l}\text { Blood-breasted } \\
\text { Flowerpecker }\end{array}$ & NIF & & & & $\mathrm{s}$ & \# & & & \\
\hline Dicaeum cruentatum & Scarlet-backed Flowerpecker & NIF & & & & $\mathrm{s}$ & $\#$ & & $\#$ & \\
\hline Dicaeum trochileum & Scarlet-headed Flowerpecker & NIF & & & & $\mathrm{s}+\mathrm{h}$ & & & \# & \# \\
\hline Dicaeum trigonostigma & Orange-bellied Flowerpecker & NIF & & & & $\mathrm{s}$ & & & & \# \\
\hline
\end{tabular}




\begin{tabular}{|c|c|c|c|c|c|c|c|c|c|c|}
\hline \multirow[b]{2}{*}{ Scientific Name ${ }^{1}$} & \multirow[b]{2}{*}{ English Name } & \multirow[b]{2}{*}{ Guild $^{2}$} & \multicolumn{3}{|c|}{ Status $^{3}$} & \multirow[t]{2}{*}{$\mathbf{P}$} & \multicolumn{4}{|c|}{ Habitat } \\
\hline & & & IUCN & CITES $^{4}$ & $\begin{array}{c}\mathbf{U U} / \\
\text { PP RI }^{5}\end{array}$ & & NF & RMP & RAF & EA \\
\hline \multicolumn{11}{|l|}{ Nectariniidae } \\
\hline Anthreptes simplex & Plain Sunbird & $\mathrm{N}$ & & & B & $\mathrm{s}$ & \# & & & \\
\hline Anthreptes singalensis & Ruby-cheeked Sunbird & $\mathrm{N}$ & & & $\mathrm{AB}$ & $\mathrm{s}$ & \# & & $\#$ & \\
\hline Anthreptes malacensis & Brown-throated Sunbird & $\mathrm{N}$ & & & $\mathrm{AB}$ & & \# & & & \\
\hline Cinnyris jugularis & Olive-backed Sunbird & $\mathrm{N}$ & & & $\mathrm{AB}$ & $\mathrm{s}$ & \# & & \# & \# \\
\hline Arachnothera longirostra & Little Spiderhunter & $\mathrm{N}$ & & & $\mathrm{AB}$ & s & \# & & & \\
\hline Arachnothera affinis & Streaky-breasted Spiderhunter & $\mathrm{N}$ & & & B & $\mathrm{s}$ & \# & & \# & \\
\hline Anthreptes rhodolaema & Red-throated Sunbird & $\mathrm{N}$ & NT & & $\mathrm{AB}$ & $\mathrm{s}$ & \# & & & \\
\hline \multicolumn{11}{|l|}{ Zosteropidae } \\
\hline Zosterops palpebrosus & Oriental White-eye & AFGI & & & & $\mathrm{s}$ & \# & \# & & \# \\
\hline Zosterops everetti & Everett's White-eye & AFGI & & & & $\mathrm{s}$ & $\#$ & & & \\
\hline Zosterops montanus & Mountain White-eye & AFGI & & & & $\mathrm{s}$ & \# & \# & & \\
\hline \multicolumn{11}{|l|}{ Estrildidae } \\
\hline Lonchura striata & White-rumped Munia & $\mathrm{TF}$ & & & & $\mathrm{s}$ & \# & & & \# \\
\hline Lonchura leucogastroides & Javan Munia & $\mathrm{TF}$ & & & & $\mathrm{s}$ & \# & & \# & \# \\
\hline Lonchura maja & White-headed Munia & $\mathrm{TF}$ & & & & $\mathrm{s}$ & & & & \# \\
\hline Padda oryzivora & Java Sparrow & $\mathrm{TF}$ & VU & II & & $\mathrm{s}$ & & & & \\
\hline \multicolumn{11}{|l|}{ Ploceidae } \\
\hline Passer montanus & Eurasian Tree Sparrow & $\mathrm{TF}$ & & & & $\mathrm{s}$ & & & & \# \\
\hline \multicolumn{11}{|l|}{ Sturnidae } \\
\hline Acridotheres javanicus & White-vented Myna & $\mathrm{AF}$ & & & & $\mathrm{s}$ & & \# & \# & \# \\
\hline Gracula religiosa & Common Hill Myna & $\mathrm{AF}$ & & II & $\mathrm{AB}$ & $\mathrm{r}$ & $\#$ & \# & & \\
\hline \multicolumn{11}{|l|}{ Oriolidae } \\
\hline Oriolus chinensis & Black-naped Oriole & AFGIF & & & & $\mathrm{s}$ & $\#$ & \# & \# & \# \\
\hline \multicolumn{11}{|l|}{ Dicruridae } \\
\hline Dicrurus macrocercus & Black Drongo & SSGI & & & & $\mathrm{s}$ & $\#$ & \# & & \\
\hline Dicrurus leucophaeus & Ashy Drongo & SSGI & & & & $\mathrm{s}$ & $\#$ & & & \\
\hline Dicrurus remifer & Lesser Racquet-tailed Drongo & SSGI & & & & $\mathrm{s}+\mathrm{h}$ & \# & & \# & \\
\hline Dicrurus sumatranus & Sumatran Drongo & SSGI & NT & & & s & \# & & \# & \# \\
\hline \multicolumn{11}{|l|}{ Artamidae } \\
\hline Artamus leucorynchus & White-breasted Woodswallow & SSGI & & & & $\mathrm{s}$ & \# & & & \# \\
\hline \multicolumn{11}{|l|}{ Corvidae } \\
\hline Dendrocitta occipitalis & Sumatran Treepie & AFGIF & & & & $\mathrm{s}$ & $\#$ & & & \\
\hline Corvus enca & Slender-billed Crow & AFGIF & & & & $\mathrm{s}$ & \# & & & \\
\hline Corvus macrorhynchos & Large-billed Crow & AFGIF & & & & $\mathrm{s}$ & \# & & \# & \# \\
\hline TOTAL & & & & & & & 122 & 30 & 46 & 39 \\
\hline
\end{tabular}

Remarks :

${ }^{1}$ Clasification name based on Sukmantoro et al. (2007)

${ }^{2}$ Clasification of guild composition based on Lambert and Collar (2002):AF=arboreal frugivore, AFGI=arboreal foliage gleaning insectivore, $\mathrm{AFGIF}=$ arboreal foliage gleaning insectivore-frugivore, $\mathrm{AFP}=$ arboreal frugivore-predator, $\mathrm{AI}=$ aerial insectivore, $\mathrm{BGI}=$ bark gleaning insectivore, $\mathrm{MIP}=$ miscellaneous insectivor-piscivore, $\mathrm{N}=$ nectarivore, $\mathrm{NP}=$ nocturnal predator, $\mathrm{NIF}=$ nectarivore-insectivore-frugivore, $\mathrm{P}=$ piscivore, $\mathrm{R}=$ raptivore, $\mathrm{SI}=$ sallying insectivore, SSGI=sallying substrate gleaning insctivore, $\mathrm{TF}=$ terrestrial frugivore, $\mathrm{TI}=$ terrestrial insectivore and $\mathrm{TIF}=$ terrestrial insectivore-frugivore. AI, N, NIF, SI, MIP, SSGI: Thisgroupof birds for age sin theair, whileflying. BGI: This group for ages in trees, by searching in ordisassemblingbark. TF, TI, TIF:This group for ages on the ground or the forest floor.

${ }^{3}$ Status: IUCN=International Union Conservation of Nature, CITES=Convention on the International Trade in Endangered Flora and Fauna, A = Undang-undang RI No. 5/1990; B = Peraturan Pemerintah No. 7/1999

${ }^{4}$ Birds' presence in location survey $(\mathrm{P}): \mathrm{s}=$ seen, $\mathrm{h}=$ heard, $\mathrm{r}=$ reported

${ }^{5}$ Habitat: NF (Natural Forest), RAF (Rubber Agroforest), RMP (Rubber Monoculture Plantation), EA (Emplacement Area) 